\title{
분쟁지역에서의 월드비전의 사업사례와 그 함의점
}

\section{전지환(월드비전 국제구호팀 팀장)}

목 차

I. 본 페이퍼의 범위

II. 분쟁과 개발의 상관관계: 취약국의 관점에서

III. 분쟁지역에서의 월드비전의 사업전략과 사업사례

IV. 결론과 제언

\section{I. 본 페이퍼의 범위}

본 페이퍼는 분쟁지역에서의 월드비전의 사업사례를 통해서 국제구호개발 NGO에 분쟁지역 사업전략과 그 함의점을 도출하고자 한다. 이를 통해서 분쟁지역에서의 국 제구호 $\mathrm{NGO}$ 들의 사업과 그 도전에 대한 이해를 높이고, 더 나아가서 향후 이와 관 계기관들이 분쟁지역 및 국가에서의 사업전략 및 사업모델을 계획하는데 기여하고자 한다. 궁극적으로는 이러한 변화를 통해서 분쟁국에서 빈곤, 안전, 사회문화적인 구 조 등으로 인한 복합적인 어려움에 직면하고 있는 아동과 취약주민들을 좀 더 효과 적으로 지원할 수 있는 방법을 모색하고자 한다.

본 페이퍼에서 다루고자 하는 범위는 우선 분쟁국에서의 개발의 도전과제들을 취 약국의 관점에서 바라보고 월드비전은 이에 대해서 어떤 전략으로 대처하려고 하였 는지를 소개하려고 한다. 그리고 실제로 분쟁국에서의 월드비전의 사업사례를 소개 하는데, 분쟁국에서의 사업경험을 통해서 월드비전이 얻었던 교훈을 통해서 사업들 을 범주화하였다. 그 교훈들은 현장의 특수성과 필요에 기인한 사업, 부작용을 최소 
화하고 평화증진에 기여하는 사업, 마지막으로 포괄적이고도 지속가능한 영향을 미 치는 사업으로 정리할 수 있다. 마지막으로 결론과 함께 분쟁국 사업의 관계기관들 을 위한 몇 가지 제언들로 마무리하고자 한다.

\section{II. 분쟁과 개발의 상관관계: 취약국의 관점에서}

분쟁국을 바라보는 여러 가지 관점이 있지만, 여기에서는 취약국이라는 논의의 틀 을 가지로 분쟁국에 대해서 논하고자 한다. 사실 취약국(Fragile States)에 대한 학 계 혹은 전 세계적인 차원에서 합의된 정의는 아직 존재하지 않고 있다. 또한 취약 국이라는 용어 자체에 대해서도 논쟁이 진행 중이기는 하다. 하지만 실용적인 관점 에서 학계 및 국제개발구호와 관련된 기관들에서 사용하고 있는 용어이기에 여기에 서도 그대로 사용하고자 한다.

영국 DFID(Department for International Development)의 Working Definition 은 취약국에 대해서 가장 널리 차용되는 정의 중의 하나인데, 이 정의에 따르면 취 약국이란 어떤 정부의 기본적 기능(basic function)이 작동되지 않거나 작동되지 않 아서 그 혜택이 국민들에게 전달되지 않는 경우를 취약국이라고 지칭한다. 여기서 정부의 기본적인 기능은 국가의 안보, 국가 내의 치안, 사회의 기본적인 서비스, 사 회의 취약계층들이 삶을 지속적으로 영위할 수 있도록 보호 및 지원, 국가의 재원을 효과적으로 운용할 수 있는 능력 등을 말한다(DFID, 2005).

위의 정의를 살펴보면, 취약국은 해당국가의 거버넌스(Governance)가 얼마나 제 기능을 하고 있느냐에 관련된 것임을 알게 된다. 이것은 때로는 해당국가의 역량에 관련된 문제이기도 하고, 또 때로는 그 국가의 의지와 관련된 것이기도 하다. 그런데 국가의 기본적 역할을 수행하지 못하는 국가의 상황들을 분석해보면 많은 경우 분쟁 으로 인해서 국가의 기본 역량이 약화되었거나 아예 역량을 가지지 못한 경우가 있 다(Browne, 2007).

실제로 UNDP에서 발행한 Human Development Report 2014에 의하면, 전체 인간 개발지수 및 각 분야별 개발지수에서 Low Development Countries(LDCs)를 기록한 
43 개 국가와 월드비전이 참고하는 취약국과 관련된 3 가지의 Index를 살펴보면 정부의 기본기능이 역할을 하지 못하는 취약국과, 분쟁국 그리고 인간개발지수와의 높은 상관 성을 발견할 수 있다(Foreign Policy, 2014; IEP, 2014; Brookings Institute, 2008).

<표 1〉3가지 취약국 관련 Index와 인간개발지수와의 상관성

\begin{tabular}{|c|c|c|c|}
\hline & $\begin{array}{l}\text { Fragile State Index } 2014 \\
\text { (Foreign Policy) }\end{array}$ & Global Peace Index 20141) & Index of State Weakness \\
\hline 1 & 남수단 ** & 시리아 & 소말리아** \\
\hline 2 & 소말리아** & 아프가니스탄 ${ }^{*}$ & 아프가니스탄 ${ }^{*}$ \\
\hline 3 & 중앙아프리카 공화국* & 남수단** & 콩고민주공화국* \\
\hline 4 & 콩고민주공화국* & 이라크 & 이라크 \\
\hline 5 & 수단* & 소말리아** & 브룬디* \\
\hline 6 & 차드* & 수단* & 수단* \\
\hline 7 & 아프가니스탄 ${ }^{*}$ & 중앙아프리카 공화국* & 중앙아프리카 공화국* \\
\hline 8 & 예멘 & 콩고민주공화국* & 짐바브웨* \\
\hline 9 & 아이티* & 파키스탄 ${ }^{*}$ & 라이베리아 * \\
\hline 10 & 파키스탄 & 러시아 & 코트디부아르* \\
\hline
\end{tabular}

출처: Foreign Policy, 2014; IEP, 2014; Brookings Institute, 2008

위의 〈표 1 〉에서는 참조한 3 개의 Index에서, 과거 5 년간 국가 내의 혹은 국가 간의 분쟁이 존재했던 국가들은 이탤릭체로 표기하였고, UNDP의 2014 인간개발지수 (Human Development Index: HDI)가 0.540이하인 국가로서 Low Human Development(LHD)를 기록하는 국가들은 *표시를 하였다. 다만 남수단과 소말리아의 경우에는 **로 표시하였는데, 이 국가들은 기타 국가 혹은 영토(Other Countries or Territory)로 분류되어서 확인할 수 있는 HDI는 존재하지 않았다. 하지만 남수단과 소 말리아의 경우 기대수명, 학교재학기간, 국민총소득2)을 보면 LDCs에 속하는 국가임을 충분히 추론할 수 있다(UNDP, 2014).

1) 2014 Global Peace Index는 표에 나온 다른 Index와 달리 가장 평화의 지수가 높은 국가가 1 위에 선정되며, 시리아는 가장 순위가 낮은 162 위이다. 여기에는 이 표의 성 격에 맞추어 변형하여서 적용하였음을 밝힌다. (IEP, 2014)

2) UNDP HDI 2014를 보면, 기대수명은 소말리아 55.1세이고 남수단은 55.3세로서 LHD 국가들의 그것과 근접하거나 낮은 상태이며 국민총소득의 경우에는 남수단의 데이터만 존재하는데 USD1,450로서 다른 $\mathrm{LHD}$ 의 범주 내에 속한다고 볼 수 있다. (UNDP, 2014) 
위에서 참조한 3 가지 Index의 상위 10 위에 해당하는 국가 중 과거 5 년간 분쟁이 있었고, 낮은 인간개발지수를 보여주는 국가들을 보면, 중앙아프리카 공화국, 수단, 파키스탄, 아프가니스탄, 예멘, 콩고민주공화국 등 6 개국이며 남수단과 소말리아도 이와 같은 범주에 든다고 볼 수 있다. 특히 Index of State Weakness의 경우에는 2008년의 결과로서 남수단이 독립되기 전의 자료임을 고려할 때, (1) 3개의 Index에 모두 등장하고 (2) 5 년에 내에 분쟁이 존재하면서도 (3) 동시에 낮은 인간개발수치를 보여주는 국가들은 소말리아. 남수단, 수단, 콩고민주공화국. 중앙아프리카 공화국. 아프가니스탄 등 6 개 국가이며, 각 국가별로 박스처리를 하였다.

위의 표를 통해서 취약국 내지 국가의 역량이 낮은 국가들의 대부분이 분쟁을 통 해서 거버넌스 기능이 약화되었고, 국가 내에 속한 국민들은 평화를 누리지 못하게 되었으며, 결과적으로 이는 국민들의 인간개발의 성취가 상당히 낮은 결과로 나타난 것으로 추론할 수 있다.

<그림 1> 나이지리아에서의 분쟁과 그 배경(Conflict in Nigeria and its background)

Indigene/Settler tensions

Historical Factors

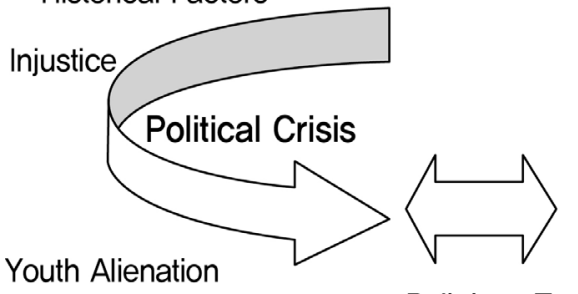

Religious Tension
Ethnic Tension

International Economic Pressures

Inequality

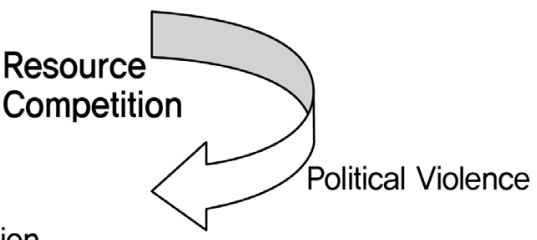

출처: UNDP, 2003

〈그림 1〉에서 보여주는 것처럼, 한 국가 내의 분쟁의 원인을 하나의 원인에서만 찾거나 분쟁과 빈곤 그리고 거버넌스의 부재를 단순한 원인-결과의 관계성에서만 찾 는 것은 지양되어야 한다. 한 국가에서 분쟁이 발생할 때에는 한가지의 독립적인 원 인으로 발생하기 보다는 여러 가지 요인들의 상호관련성 가운데 발생하는 경우가 많 다. 또한 분쟁과 빈곤 그리고 거버넌스의 부재는 서로 원인인 동시에 결과가 되는 
상당히 복잡한 상관관계라는 인식하에서 분쟁과 개발을 바라보는 것이 올바른 관점 이다(UNDP, 2003).

\section{III. 분쟁지역에서의 월드비전의 사업전략과 사업사례}

\section{1. 분쟁국에서의 기존 개발모델의 한계와 도전}

기본적으로 월드비전의 장기지역개발사업은 10-15년의 지역개발사업을 통해서 일 정 지역의 빈곤아동들의 Child-Wellbeing을 높이는 사업모델을 가지고 있다(World Vision, 2011). 월드비전이 추구하는 Child-Wellbeing은 교육, 보건, 영양, 사회적 관계에서의 아동들이 월드비전의 지역개발사업을 통해서 얼마나 변화를 경험하는가 에 초점이 맞추어져있다.

그런데 이러한 장기개발 사업을 진행하기위한 두 가지 선결조건이 있다. 먼저 지 역개발사업을 실행할 수 있는 일정규모의 지역사회가 존재해야 하고, 정치사회적으 로 어느 정도의 안정성이 보장되어서 10-15년간의 개발 사업이 진행될 수 있는 환경 을 조성해야 한다. 이렇게 조성된 환경을 통해서 장기적으로 효과적인 지역사회개발 사업이 진행될 수 있다.

하지만 월드비전은 그동안 개발 사업을 진행하면서 기존의 장기개발사업의 모델로서 는 적용되지 않는 다양한 종류의 상황들을 경험하게 되었다. 구체적으로는 유목민 그 룹, 오지(remote area)에서 거주하는 소규모의 주민들, 도시의 빈민가(Urban Slum), 그리고 분쟁국이 대부분을 이루는 취약국(Fragile Sates)이 그러한 상황들이다.

특히 영국 월드비전에서 발행한 내부문서에 의하면, 2015년에서 2020년 사이의 빈곤인구가 점차 분쟁국(conflict-affected areas or countries) 혹은 변경지역 (marginal land of countries)에 위치하게 될 것이라고 예측하고 있다. 이러한 지역 에서 거주하는 아동 및 주민들은 점차적으로 정부의 기본적인 사회서비스 혹은 거버 넌스의 혜택으로의 접근성이 어려워지고, 오히려 책임성이 결여된 집단 즉 무장세력, 범죄와 관련된 세력의 통제가 점점 강화되는 보이게 될 것이라고 전망하고 있다 
(Midgley et al., 2011). 실제적으로도 월드비전은 분쟁국을 포함한 취약국에서 사업 을 진행하면서 몇 가지 특정한 어려움들에 봉착하였다. 그 도전들을 다음과 같이 정 리하였다(DFID, 2005).

\section{1) 장기적인 사업개발 및 전략수립의 어려움}

지역개발사업(Area Development Programme)모델은 10-15년의 장기적인 사업자 금의 지원이 이루어지는 반면에, 장기적인 지역개발사업의 실행이 불가능한 분쟁국 을 위한 펀딩은 대체로 제도적 후원기관(Institutional Donor)으로부터의 자금이 대 부분이고, 사업기간도 길어봐야 1-3년에 한정되는 경우가 대부분이다. 이런 상황에 서는 지역의 장기적이고도 지속가능한 효과를 생산할 수 있는 사업개발 및 전략수립 에는 어려움이 있다. 이러한 상황에서는 그 지역이나 국가의 장기적인 전략에 맞추 어서 사업전략이나 개발이 진행되는 것이 아니라, 사업자금의 가능성(available funding)이나 후원기관의 자원배분에 전략과는 상관없이 쫓아갈 수밖에 없게 된다.

2) 상대적으로 높은 분쟁국에서의 사업운영비(Overhead cost)혹은 간접비의 비율

분쟁국을 포함한 취약국에서는 일반적으로 사업운영비의 비율이 상당히 높다. 그 이유로는 분쟁국 내의 거버넌스, 사회자본의 부재, 제조업의 부재 등으로 인해서 대 부분의 사업진행을 위한 물자를 수입해야 하고 이를 현장으로 이동하는 과정에도 상 당히 높은 물류비용이 소비된다.

인적자원의 측면에서도 오랜 분쟁으로 인해서 사업개발 및 관리를 위한 일정수준 이상의 교육을 받은 현지직원을 구하기 어려워서 외국인 직원의 비율이 높은 까닭에 인력비의 비율도 높다. 또한 대부분의 사업이 단기성 프로젝트인 관계로 대부분 프 로젝트 단위로 인력이 채용되는 현장에서는 단기성 사업이 종결되는 그대로 계약을 해지할 수밖에 없어서 인재를 새롭게 채용하는데 시간과 자원이 소비될 수밖에 없다. 
분쟁국의 경우에는 직원 안전 혹은 물자보호 등의 부수적인 비용이 추가로 소비되 어야 한다. 마지막으로 분쟁국의 특성상 사회의 불확실성이 높고 정부의 거버넌스의 역량도 현저히 부족하여 사업이 지연되는 경우가 많아서 이러한 이유로 추가적인 비 용이 요구되는 경우가 많다. 이러한 이유들로 상대적으로 높은 사업운영비 혹은 간 접비에 대해, 또한 많은 후원기관들이 지원하기를 꺼려하기 때문에, 분쟁국 사업개발 및 지원에 어려움의 악순환이 지속되는 것이다.

\section{3) 분쟁국에서의 협력파트너 역량 혹은 의지의 부재}

$\mathrm{NGO}$ 가 일정지역에서 사업을 계획 및 개발, 수행, 그리고 종결까지는 여러 단계의 파트너들과 협력해야 한다. 국가, 지방정부, 종교지도자, 지역사회 그리고 지역의 시 민사회(Civil Society Organization) 혹은 비공식적인 사회네트워크를 포함하여 분쟁 국에서는 이들의 역량이 현저히 낮거나 혹은 의지가 부족한 경우가 많다.

\section{4) 지역사회의 의존성}

분쟁의 장기화가 고착된 지역에서는 지역사회의 주민들이 외부기관의 지원에 의존적인 성향을 갖게 되는 경우가 많다. 이러한 환경에서 어떤 NGO가 지역사회 주민들에게 단기 적인 물자지원 서비스를 제대로 이행하지 못한다고 인식될 때에는 더 이상 사업을 진행 하기가 어려운 경우가 많다. 또한 이런 환경에서는 자발적인 주민참여의 문화-(Voluntary Culture) 혹은 주인의식(Ownership)의 문화를 정착하는 것이 상당히 어렵다.

\section{2. 월드비전의 분쟁국에서의 사업사례}

기존의 개발사업 모델로서는 분쟁국의 취약한 주민들에 대한 인도적 지원이 점차 적으로 어려워질 것이라는 인식하에서, 월드비전은 기존의 장기적인 지역개발모델을 넘어서서, 분쟁국을 포함한 취약국의 특수성에 맞는 사업모델을 고민하였다. 저자는 여기서 월드비전의 분쟁국에서의 사업을 통한 교훈들을 3 가지로 요약하여 범주화하 고자 한다. 물론 이 범주화는 저자에 의한 것으로서, 다른 기관들의 분쟁국에서의 사 업에도 동일하게 적용될 수 있음을 밝힌다. 
분쟁국에서의 3 가지 교훈은 1) 지역사회 주도의 재건사업을 통해 지속가능한 효과 가 있을 수 있는 사업(Bring a sustainable impact); 2) 현장의 특수성과 필요에 기인한 사업(context-specific); 마지막으로 3) 부작용을 최소화하고 평화증진에 기 여하는 사업(Do no Harm)으로 정리할 수 있다.

\section{1) 재건사업을 통한 포괄적이며 지속가능한 효과성을 가져오는 사업(Bringing a sustainable impact)}

월드비전은 위에서 열거한 분쟁국에서의 사업진행의 도전과 어려움을 절감하면서 분쟁국을 포함한 취약국에 적합한 사업모델 및 전략에 대한 교훈을 통해서 지역사회 주도의 재건사업모델을 수립하였다. 그것은 지역재건사업(Area Rehabilitation Programme: ARP)과 지역주도사업(Community Driven Initiative: CDI)모델이다.

(1) 지역재건사업(ARP)을 통한 포괄적이고도 지속가능한 사업효과성 추구

이제까지는 각각 다른 지역에 다른 사업 분야를 가지고 단기간의 사업이 일관된 사업전략이 부재한 상태로 진행되었다. 그 결과 국가 전체적으로나 지역사회에 지속 가능한 사업효과를 가져다주지 못했다. 이에 월드비전은 3-5년의 중기사업 모델을 가지고 지역의 필요에 따라서 3-4개 사업분야(sector)를 가진 지역재건사업(ARP)을 진행하고 있다.

월드비전은 수단, 남수단, 소말리아, 스리랑카 등의 과거에 분쟁의 피해가 있었거 나, 현재 분쟁이 지속되는 국가에서 지역재건사업을 실시하고 있다. 단기적인 구호단 계와 장기적인 개발단계의 중간 지점에 속한 재건사업으로서, 기존의 구호와 개발을 나누는 이분법적인 개념을 넘어선 '개발을 지향하는 구호'(Developmental Relief)와 맞닿아 있다. 한국 월드비전이 실시하였던 두 가지의 지역재건사업을 소개하자면 다 음과 같다. 
(1) 우간다 울 지역재건사업(2011년-2013년)

본 사업은 20 여 년간의 장기간 분쟁으로 피폐화된 북부 우간다 울지역(Wol area, Agago District)에서 3년간의 재건계획(Rehabilitation Program)과 이를 장기적인 개발계획으로 연결시키기 위한 월드비전의 지역재건사업(Area Rehabilitation Programme: ARP)에 기반을 둔 사업이다. 그리하여 본 사업은 다양한 지역사회의 필요를 고려해서, 농업, 영양, 교육, 소액금융(Micro-finance), 그리고 심리사회적 치료를 포함하는 통합적(Integrated)이고 포괄적(Comprehensive)인 사업이다(한국 월드비전, 2010).

(2) 수단 마요 지역재건사업(2012-2015년 3월 종결예정)

본 사업이 시행되고 있는 마요(Mayo) 지역 [혹은 마요 국내 실향민캠프(Mayo IDP Camp)라고 불리기도 함]은 수단의 남부 혹은 서부에서 1990년 이래로 이주한 10만 명 이상이 운집한 국내 실향민들의 거주지이다. 남수단, 콩고민주공화국, 차드, 우간 다 등에서 이주한 난민들도 이 지역에 머물고 있는 상황이다. 월드비전은 2011년 10 월경에 본 '마요지역재건사업'을 위한 사전조사(Rapid Assessment)를 실시하여 지역 주민들의 특정한 욕구(Need)들을 조사하였고, 이 욕구와 월드비전이 현재까지 진행 하였던 다양한 사업들과의 괴리(Gap)를 발견하고, 이를 채워나가는데 기여하고자 하 였다. 이를 바탕으로 여성을 위한 생계지원(Livelihood), 식수위생(Water and Sanitation), 보건 및 영양(Health \& Nutrition), 교육(Education)사업을 실시하고 있다(한국 월드비전, 2011).

월드비전은 지역재건사업이 순조로이 진행되고 종결될 경우, 이 지역을 아동결연 에 기반을 둔 장기적인 지역개발사업(Area Development Programme: ADP)과 연계 하고 있다. 물론 그 전제는 해당국가나 지역이 정치사회적으로 안정화될 때 이러한 개발 사업으로의 전이(Transition)가 실현될 수 있다. 실제로 스리랑카 북부 혹은 우 간다 북부 지역에서는 이와 같은 개발 사업으로의 전이가 실현되고 있다. 
(2) 지역사회 주도적인 사업모델 개발(Community Driven Initiative)

월드비전이 현재 파키스탄의 북서부 지역에서 시행하고 있는 지역통합사업(Area Integrated Programme)의 경우에는 우선적으로 지역사회 내에 존재하는 마을개발 회(Village Development Community)를 파악하고 협력을 강화하거나, 혹 존재하지 않는 경우에는 관련 모임을 조직하는 것으로 시작한다. 월드비전 직원은 이들과 협 력하여 지역사회의 필요와 우선순위를 반영한 마을개발계획(Village Development Plan)을 수립한다(Midgley et al., 2011). 본 사업모델의 가장 핵심적인 부분은 이렇 게 구성된 마을개발계획에 지역사회 자신들에 의해서 사업자금이 일정부분 충당되어 야 한다는 것이다. 즉 지역사회 스스로의 기여가 핵심요소이다. 보통은 지역사회가 관련 프로젝트의 적어도 $20 \%$ 를 충당하도록 하고 또한 지역사회가 노동력으로도 기 여하도록 한다. 월드비전은 여기서 퍼실리테이터(Facilitator)와 역량강화를 돕는 역 할만을 담당하는 것이다. 이렇게 지역사회 주도형 개발모델은 다른 국제NGO의 개발 모델형성에도 영향을 주고 있다.

\section{2) 현장의 특수성과 필요에 기인한 사업(Context-Specific)}

개발사업계에서 종종 쓰이는 “One Size Fits All”라는 문구가 있다. 보통 하나의 스타일 혹은 과정이 모든 상황에 적용된다는 의미로 사용되는 이 문구는 상황에 따 라서 긍정적으로 또한 부정적으로도 사용되는데, 개발사업 혹은 인도적 사업 내에서 이 문구가 쓰일 때에는 인도적 지원 혹은 개발사업 주체가 현장의 상황을 충분히 고 려하지 않고 특정한 사업모델이나 방식을 무분별하게 진행하는 경우를 빗대어 사용 되는 경우가 많다.

분쟁국에서 인도적 지원 혹은 개발 사업을 진행할 때에도 이 교훈은 동일하게 적 용된다. 현상적으로는 유사해 보이는 분쟁이 발생한다고 해도, 각 분쟁의 원인을 분 석해보면 다른 접근방법이 요구된다는 것을 알게 된다. 이러한 이유로 분쟁국에서 사업을 진행하기 전에는 분쟁에 대한 철저하고도 정확한 이해와 분석이 요구된다. 
(1) 분쟁을 분석하는 도구: 월드비전의 MSTC(Making Sense of Turbulent Context)

분쟁국이나 혹은 정치적인 불안정의 영향 내에 있는 국가들의 상황을 분석하는 도 구들이 이미 개발되어서 사용되고 있다. 먼저 월드비전의 경우에는 MSTC라는 분석 도구를 사용하고 있다. 이 분석방법은 참가자들의 참여를 통해서 국가적 혹은 지역 적 차원에서의 분쟁, 정치경제적 상황 등을 분석하기 위해서 분쟁의 역사, 관련자, 현상, 정치경제적 경향 및 촉진요인에 대한 정보를 모으고 이를 분석한다.

MSTC는 분쟁에 영향을 미치는 요인들을 두가지의 범주로 나눈다. 하나는 불만 (Grievance)의 요인이고 여기에는 문화, 역사, 종교, 언어 등이 속한다. 그리고 탐욕 (Greed)의 요인인데 여기에는 경제와 정치, 그리고 승자와 패자 등이 속한다. 그리고 이러한 두 범주의 요인이 어떻게 그 상황의 취약계층들에게 영향을 미치는지를 분석 한다. 분쟁상황에서의 승자와 패자를 바라보는 정치경제적인 측면에서의 분석에 사 회역사적인 요소를 보완하여 한 지역에서 발생하는 분쟁에 대한 정치, 경제, 역사, 사회적인 복합적인 요인들을 하나씩 분석해나가는 방식이다(World Vision, 2012).

MSTC는 'Do No Harm'의 원칙에 기반을 두고 있다. 상황에 적절하지 않은 인도 적 지원 사업이나 지원된 자원 혹은 물자가 의도와는 다르게 악용되는 사례가 분쟁 지역에서는 종종 발견된다. 분쟁 원인과 분쟁과 관련된 당사자들에 대한 정확한 분 석이 없는 경우에는 오히려 인도적 지원 혹은 개발 주체들의 자원들이 전쟁을 장기 화시키는 등의 심각한 부작용을 초래할 수 있다. 그러기에 MSTC에서는 NGO들이 어 떻게 전쟁이 아닌 평화를 지원하는 방향으로 사업이 이루어질 수 있고, 또한 국가적 혹은 국제적 차원에서 어떻게 관련 정책에 영향을 미칠 수 있는지에 대한 옹호사업 의 방향성에 대해서도 다루고 있다(World Vision, 2013).

(2) 우간다 북부지역의 심리사회적 치료사업 및 소년병 재활지원사업(Formerly Abducted Children Rehabilitation \& Wol Area Rehabilitation Programme)

우간다에서 반란 무장 세력인 신의 저항군(Lord Resistance Army: LRA)으로 인 해 장기화된 분쟁은 특히 북부 우간다 지역에서 20년이 넘게 진행되었다. 이로 인해 서 약 1.6 million 명의 주민들이 그들의 고향을 떠나 우간다 각지로 흩어져 국내 실 
향민캠프(Internally Displaced Persons Camps)를 형성하였다. 국내 실향민(IDPs)으 로 고향을 떠난 이들은 그들이 가지고 있던 생산 자산(Production Assets), 사회적 설비(Social Amenities), 그리고 그들의 생활터전을 버리고 떠날 수밖에 없었다. 뿐만 아니라, 국내 실향민캠프에서의 생활은 가능한 생계수단을 극도로 제한시켜서 극심한 빈곤상태에 빠지게 하고, 결과적으로 높은 유아 사망률과 아동의 높은 영양실조, 학 교 등록률의 저하 및 낮은 교육 이수율, 그리고 HIV/AIDS의 확산을 가져왔다.

다행히 2006년 8월 26일에 수단의 주바(Juba)에서 우간다정부와 신의 저항군 사 이에 '적대행위 중지에 대한 협정'(Cessation of Hostilities Agreement)이 맺어짐에 따라서 우간다 북부지역의 상황은 상당히 개선되었다. 2010년 5월까지 파데르 지구 (현 아가고 지구)의 $95 \%$ 의 국내 실향민들이 국내 실향민캠프로부터 고향으로 귀환했 다는 사실이 이 지역의 상황이 개선되었다는 것을 증명한다. 하지만 우간다 북부로 귀환한 국내 실향민들은 대부분 과거 우간다 정부와 '신의 저항군'간의 분쟁기간 동 안 국내 실향민캠프에서 최대 20여 년 동안 머물면서 유엔 및 NGO의 물품이나 식량 을 통해서 살아왔다. 그러기에 주민들 대부분이 농업 등 생계수단으로 살아가기 위 한 충분한 지식과 기술을 가지고 있지 못하다. 또한 2009년부터 시작된 식량배급계 획 축소 및 종결계획은 식량상황을 더욱 어렵게 하였다.

생계지원, 식량, 영양의 문제도 이 지역 주민들에게 큰 어려움이지만, 장기화된 분 쟁은 북부 우간다 주민들에게는 큰 정신적인 상처를 남겼다. 굴루대학교의 의학부와 런던대학교가 2008년에 실시한 연구에 의하면, 이 지역 국내 실향민 중에서 외상 후 스트레스 장애(Post Traumatic Stress Disorder)로 고통 받는 비율이 상당히 높은 것으로 나타났다. 이 조사에 의하면, 절반이 넘는 응답자 $(54 \%)$ 가 외상 후 스트레스 장애에 속하며, $2 / 3$ 의 응답자들 $(67 \%)$ 은 우울증으로 고통을 당하고 있다고 밝히고 있 다(Robert, 2008).

2009년에 실시된 조사에 의하면, 파데르 지구(현재 아가고 지구)에서 월드비전 우 간다가 사업을 시행하는 지역의 14 세에서 17 세에 속하는 874 명의 아동 중 $78 \%$ 의 아 동들에게서 우울증이 발견되었다. 이러한 심리적 상태는 파데르 지구에 속한 아콜리 (Acholi) 지방 전역에서 공통적으로 발견되고 있다. 
이러한 상황에서 월드비전은 전쟁피해가 가장 심한 지역 중의 하나였던, 아가고 지구 (Agago District) 울 지역에서 농업, 교육, 영양 분야를 포괄하는 지역재건사업 을 2011년부터 2013년까지 3년 동안 KOICA 민간지원협력사업으로 총 8억 8천만 원 의 예산으로 진행하였다. 특히 이중에서도 지역 아동의 심리적 상황에 대한 개입이 필요함을 절감하고, 아동들을 대상으로 심리사회적 개입을 사업의 한 분야로 실시하 였다.

전쟁피해 아동에 대한 심리적 회복 및 치료는 '그룹을 통한 상호인격치료' Interpersonal therapy for groups: IPTG)를 통해서 이루어진다. 본 치료는 정신적 외상 (Trauma)적인 경험을 가지고 있는 사람들을 위한 그룹치료의 한 방법이다. 우간다 북부지역은 오랜 기간의 분쟁으로 인해서 그 지역의 사람들이 여러 사건들을 통해서 이러한 정신적 외상에 노출이 되어왔다. 이 지역의 주민 중에는 과거에 사람들이 전 쟁에서 살해당하는 장면을 목격하거나, 자녀들이 납치되고, 혹은 소년병으로 끌려가 서 다른 사람들을 죽이는데 이용된 경험을 가지고 있는 사람들이 많이 있다. 월드비 전 우간다는 이미 과거에 납치된 경험이 있는 주민들을 대상으로 재활센터(Centre for Rehabilitation)를 운영하고 있는데, 이러한 치료의 과정은 대상자들의 치료와 지역사회로의 복귀에 큰 역할을 하고 있다. 
〈표 2〉 월드비전 우간다 울 지역재건사업 심리사회적 치료분야 세부추진방향

\begin{tabular}{|c|c|c|}
\hline \multirow{6}{*}{$\begin{array}{l}\text { 심리 } \\
\text { 사회적 } \\
\text { 치료 }\end{array}$} & \multirow{3}{*}{$\begin{array}{c}\text { 상호 } \\
\text { 인격 } \\
\text { 치료 } \\
\text { 그룹 } \\
(\text { IPTG3)) } \\
\text { 조직 } \\
\text { 및 } \\
\text { 활동 }\end{array}$} & $\begin{array}{l}\text { - 프로그램 실시 전 조사 실시(Pre-Assessment) } \\
\text { : 본 조사(pre-assessment)는 정신적 외상과 스트레스의 정도를 } \\
\text { 조사하여, 본 프로그램이 필요한 학생들을 또한 파악하기 위 } \\
\text { 함이다. }\end{array}$ \\
\hline & & $\begin{array}{l}\text { - } 14 \text { 개 상호인격치료그룹 과정이 마친 후에 조사 실시 (Post- } \\
\text { Assessment) } \\
\text { : 본 조사는 그룹치료가 성공적이었는지를 평가하는 과정이 됨. }\end{array}$ \\
\hline & & $\begin{array}{l}\text { - } 14 \text { 명의 퍼실러테이터(Facilitator)와 지역사회대상 퍼실러테이터 } \\
\text { 들을 위한 발표회 } \\
\text { : 본 심리사회치료의 성격상, 심리치료 담당자들이나 퍼실러테 } \\
\text { 이터들도 심리사회적 영향을 받게 될 위험이 있다. 그러기에 } \\
\text { 본 발표회를 통하여 담당자들이 치료받고 회복되는 기회를 } \\
\text { 가지게 될 것이다. }\end{array}$ \\
\hline & \multirow{3}{*}{$\begin{array}{l}\text { IPTG에 } \\
\text { 대한 교육 } \\
\text { 및 감독 }\end{array}$} & $\begin{array}{l}\text { - } 14 \text { 개의 상호인격치료그룹의 퍼실러테이터(facilitator)를 위한 훈련 } \\
\text { : 각 훈련과정에는 } 1 \text { 개의 그룹이 참여하게 될 것이다. 각 훈련 } \\
\text { 과정은 } 4 \text { 개월이 소요될 것이다. 또한 한 과정마다 } 1 \text { 명의 퍼실 } \\
\text { 러테이터가 선정될 것이며, 자신의 역할을 수행할 것이다. 퍼 } \\
\text { 실러테이터들은 IPTG모델에 따라 훈련받고, 그룹에 투입될 것 } \\
\text { 이다. 퍼실러테이터 또한 지역사회에서 선정될 것이다. }\end{array}$ \\
\hline & & $\begin{array}{l}\text { - 치료과정을 수행하는 } 14 \text { 명의 퍼실러테이터들을 위한 지지와 감독 } \\
\text { : 이 지지와 감독에는 퍼실러테이터들이 역할을 수행하는 동안 } \\
\text { 교통편을 제공하고, 점심을 제공하는 것을 포함한다. 적어도 } \\
\text { 1주에 } 1 \text { 차례이상 실시될 것이다. }\end{array}$ \\
\hline & & $\begin{array}{l}\text { - 심리적 지지와 아동보호에 대한 상호인격치료그룹에 소속된 } \\
100 \text { 명의 교사와 } 168 \text { 명의 학부모들에 대한 } 5 \text { 회 훈련실시 } \\
\text { : 본 심리사회적 분야의 사업의 대상 아동의 학부모와 교사들이 } \\
\text { 본 훈련을 받게 될 것이다. 본 훈련은 그들이 어떻게 정신적 } \\
\text { 외상에 힘들어하는 아동들을 가정이나 학교에서 도와서 치료 } \\
\text { 의 과정이 효과적으로 이루어지게 하기 위함이다. }\end{array}$ \\
\hline
\end{tabular}

출처: 한국 월드비전, 2010

3) 상호인격그룹치료(Inter-Personal Therapy for Groups)는 충격적인 사건을 통해서 극 단적인 정신적 외상을 경험한 사람들을 위한 그룹을 통한 치료방법이다. 북부 우간다 지역은 장기간의 분쟁으로 인해서, 생존자들은 자신들의 가족이나 가까운 사람들과 헤 어지거나 죽는 것을 목격하거나, 아동들은 납치되고, 혹은 소년병으로 끌려가서 사람 을 죽여야만 했던 경험들을 가지고 있다. 월드비전 우간다는 이미 과거에 납치되었던 개인들을 위한 치료센터를 운영하면서 치료프로그램을 시행했던 경험을 바탕으로 정신적 외상에 시달리는 사람들이 정신적 외상에서 치료되고 지역사회로 통합(Reintegration) 되 는 것을 목표로 하는 본 치료프로그램을 시행하려고 한다. 
특히 본 사업은 IPTG을 통해 정신적 외상의 경험을 통해서 우울증을 경험하고 있 는 많은 사람들이 정신적 질병을 이겨나가도록 돕는 것을 목표로 하고 있다. 결과적 으로 이 치료 과정의 참가자들은 학교교육이나 생계활동에 더 적극적으로 참여할 수 있게 될 것이다. 본 사업은 또한 학교 교사와 학부모들의 역량을 강화하여 우울증세 가 있는 아동과 청소년들의 증상을 파악할 수 있도록 돕고, 그들에게 적절한 치료와 정서적 지지를 줄 수 있는 단계에 이를 수 있도록 한다. 〈표 2〉에서는 구체적으로 북부 우간다 지역에서 월드비전의 심리사회적 치료사업이 어떻게 진행되는지에 대한 세부추진방향에 대해서 설명하고 있다.

또한 위에서 언급된 것처럼, 월드비전은 북부 우간다에 위치한 글루라는 도시에 전쟁피해 아동 및 주민들의 재활을 지원하는 재활센터(Centre for Rehabilitation)를 설립하여 전쟁 피해 주민 및 소년병과 같은 피해아동을 대상으로 하는 사업을 지속 적으로 진행해왔다. 특히 월드비전이 2011-2012년에 진행하였던 소년병 재활지원 사 업(Child Solider Rehabilitation Project)은 다음의 3가지 사업목표를 가지고 진행 되었다. 1) 납치로부터 구출된 소년병을 포함한 전쟁피해 아동의 회복과 재활을 지원 한다; 2) 전쟁피해 아동의 사회복귀 및 가족과의 연합을 지원한다; 3) 전쟁피해아동 이 경험하고 있는 심리적 육체적 필요를 적절하게 채운다. 이들에 대한 구체적인 사 업 활동을 사업로그프레임의 산출물(Output)과 사업활동(Activity)으로 살펴보면 다 음과 같다.

<표 3> 소년병 재활지원사업의 사업 활동 로그프레임

\begin{tabular}{l|l}
\hline Output 1.1 & 전쟁피해아동 접수, 재활 및 가족과의 연합지원 \\
\hline & $\begin{array}{l}\text { : 납치되었다가 우간다로 귀환한 전쟁피해아동들은 1:1 상담을 통해서 } \\
\text { 심리적 상태를 검사하고, 미술치료 혹은 집단 상담 등을 통해서 각 } \\
\text { 개인에게 어떤 심리적 개입이 가장 적절할지를 결정한다. 만일 각 아 } \\
\text { 동에게 우울증 혹은 외상 후 스트레스 장애등이 발견되면 가족과의 } \\
\text { 연합 전에 이들에 대한 심리적 치료를 실시한다. 또한 각 개인의 필요 } \\
\text { 대로 의료적 지원 과 재활센터에서 지낼 수 있도록 지원한다. }\end{array}$ \\
\hline Activity 1.1.1 & 전쟁피해아동 접수, 확인, 서류작업, 생필품 지원, 숙소배정 \\
\hline Activity 1.1.2 & 심리적 치료 및 개입 실시 \\
\hline Activity 1.1.3 & 전쟁피해아동 가족을 추적하고 재연합 추진 \\
\hline Output 1.2 & 전쟁피해아동에게 의료적 지원을 실시 \\
\hline
\end{tabular}




\begin{tabular}{|c|c|}
\hline & $\begin{array}{l}\text { 납치에서 풀려나서 센터에서 지내게 되는 전쟁피해아동은 많은 경 } \\
\text { 우에 전쟁과 관련된 질병 및 상해로 고통을 받고 있다. 주로 파편 } \\
\text { 혹은 총알이 몸속에 박혀 있는 경우가 많고 혹은 신체의 일부가 상 } \\
\text { 해를 입었거나 장애로 고통을 당하고 있다. 결과적으로 어떤 아동들 } \\
\text { 이나 주민들은 몸의 일부가 마비가 되었거나 신체장애를 가지고 살 } \\
\text { 아가거나, 일부 여성들의 경우에는 강간 등의 피해로 산부인과 관련 } \\
\text { 질병으로 고통을 받는 경우가 있다. 이러한 육체적 상해 및 장애를 } \\
\text { 가지고 살아가는 아동들에게 의료적 지원을 실시한다. }\end{array}$ \\
\hline Activity 1.2 .1 & 전쟁피해 아동별 신체장애의 상태를 확인한다. \\
\hline Activity 1.2 .2 & 진단별 의료적 지원을 실시한다. \\
\hline Activity 1.2 .3 & 차후 상태를 모니터링하고 차후 조치를 실시한다. \\
\hline Activity 1.2 .4 & 필요시 관련 파트너 기관과 협력하여 추가적인 지원을 실시한다. \\
\hline Output 1.3. & $\begin{array}{l}\text { 전쟁피해아동에게 심리적 지원을 실시하고, 지역리더, 교사 등을 } \\
\text { 대상으로 인식교육을 실시한다. }\end{array}$ \\
\hline & $\begin{array}{l}\text { 관련 조사에 따르면 우간다 북부지역의 외상 후 스트레스 장애와 } \\
\text { 우울증의 비율이 상당히 높은 것으로 나타났다. 월드비전은 상호인 } \\
\text { 격그룹치료(Inter-Personal Therapy for Groups)를 통하여 전쟁피해아 } \\
\text { 동들의 심리적 상태를 개선하고, 지역리더들을 중심으로 지역주민들 } \\
\text { 에게 심리사회적 개입의 필요성에 대한 인식교육을 실시한다. }\end{array}$ \\
\hline Activity 1.3 .1 & IPTG 개입 전 사전심리상태 조사 실시 \\
\hline Activity 1.3 .2 & IPTG를 실시 \\
\hline Activity 1.3 .3 & 사후 검사 실시 \\
\hline Activity 1.3 .4 & 교사 및 지역리더들에게 IPTG의 퍼실러테이터로서의 교육 실시 \\
\hline \multirow[t]{2}{*}{ Output 2.1} & 전쟁피해 아동들에게 기초교육 및 직업교육(Vocational Training)을 실시 \\
\hline & $\begin{array}{l}\text { 높은 비율의 전쟁피해아동들이 가난으로 인해서 학교에서 중퇴하고 } \\
\text { 또한 결과적으로 적절한 교육을 받지 못해서 빈곤하게 살아가는 경 } \\
\text { 우가 많다. 이에 따라서 적절한 기초교육을 실시할 뿐만 아니라, 시 } \\
\text { 장성이 있는(Marketable)한 직업교육을 통해서 자립할 수 있는 길을 } \\
\text { 마련한다. }\end{array}$ \\
\hline Activity 2.1 .1 & 해당 전쟁피해 아동들의 상태와 필요를 파악한다. \\
\hline Activity 2.1 .2 & 직업교육을 제공할 수 있는 파트너기관을 협력관계를 맺는다. \\
\hline Activity 2.1 .3 & 기초교육(읽기, 쓰기, 기초수학) 등의 기초교육을 제공한다. \\
\hline Activity 2.1 .4 & 관련 교육자료를 제공한다. \\
\hline Activity 2.1 .5 & 직업교육을 실시한다. \\
\hline Output 3.1 & 본 사업에 참여한 전쟁피해아동들이 옹호활동에 참여한다. \\
\hline Activity 3.1 .1 & 관련 전쟁피해 아동들이 옹호활동에 참여하도록 지원한다. \\
\hline
\end{tabular}




\begin{tabular}{l|ll}
\hline Activity 3.1.2 & 3개의 옹호활동 그룹을 조직한다. \\
\hline Activity 3.1.3 & 성차폭력(Gender-based Violence)에 관련된 교육을 실시한다. \\
\hline Activity 3.1.4 & 관련 메시지가 포함된 자료를 제공한다. \\
\hline Activity 3.1.5 & 관계된 그룹의 활동을 모니터링 한다. \\
\hline
\end{tabular}

출처: World Vision South Sudan, 2014b

전쟁피해아동 지원 사업을 실시할 때 월드비전이 모든 사업 분야의 전문성과 역량 을 보유하고 있지는 못하다. 예를 들어서, 피해아동에 대한 직업교육의 경우에는 직 업교육에 역량과 전문성을 보유한 한 일본 NGO와 협력하여 교육을 위탁하였다. 이 와 같이 한 기관이 모든 사업 분야에 확장하는 것보다는, 각자의 전문성을 공유하여 관련 기관들이 협력하는 것도 향후에 고려해볼만한 사업의 방향성이다.

(3) 소말리아 누공피해자 지원사업(Fistula Victim Support Project)

대표적인 취약국 중의 하나이자 분쟁피해국인 소말리아는 여성할례(Female Genital Mutilation/Cutting)의 피해가 가장 큰 나라 중의 하나이다. 한 조사에 따 르면 소말리아의 전체 여성인구의 약 $98 \%$ 가 여성할례를 경험했다고 전해진다. 잘 알 려진 것처럼, 여성할례는 많은 경우에 상당히 비위생적인 방법으로 행해지고 이 과 정에서 과다출혈 혹은 감염으로 숨지는 여성도 적지 않다. 혹시 숨지지 않았다고 하 더라도, 다양하고도 장기적인 측면에서 여성에게 피해를 입힌다.

직장질루(Rectovaginal Fistula: RVF)와 방광질루(Vesicovaginal Fistula: VVF) 는 여성할례의 결과로 나타나는 대표적인 질병 중의 하나이다. 물론 직장질루와 방 광질루가 폭력적인 강간으로 인해서 발생하는 경우도 많다. 물론 강간의 사례가 실 제적으로 보고되는 경우는 없는데, 그 이유는 소말리아에서 피해자가 강간에 대해서 공개적으로 언급하거나 문제제기를 하는 것은 불가능하기 때문이다. 더 나아가서 산 과적 합병증으로 인해 신체적 고통을 넘어선 정신적 외상을 가지고 살아야 하는 경 우도 많다. 왜냐하면 이러한 종류의 질병은 신의 저주로 인식되는 경우가 많기 때문 에, 이러한 질병에 걸린 여성은 가정과 마을에서 고립되고, 한 인간으로서 견딜 수 없는 모멸감을 가지고 살아야 한다. 
소말리아 여성들에게 흔한 산과적 누공(Obstetric Fistula)의 경우에는 강요된 조 혼(Early Marriage)으로 인한 경우가 많다. 소말리아에서 특히 농촌지역의 경우에는 약 $50 \%$ 가 넘는 여성들이 강요된 조혼을 경험한다. 골반발육이 부진한 상태에서 분만 을 하면 태아의 머리가 질 혹은 방광조직을 오랫동안 눌러서 조직이 괴사가 발생하 고 결과적으로 구멍이 발생하는 것이다(권경성, 2008). 이 경우 산과적 누공이 발전 하면서 대소변을 조절할 수 없게 된다. 결과적으로 큰 수치를 당하게 되고 남편과 지역사회에서 거부되고, 소외된 채로 살아가게 된다(World Vision Somalia, 2012).

질 원개 탈출증(Vaginal Vault Prolapse) 또한 소말리아 여성들에게 흔한 질병 중 의 하나인데 이 질병은 위에서 언급된 질병과 함께, 여성할례로 인해 골반(Pelvic), 질 조직(Vaginal tissues), 근육 등의 연약함으로 인해서 발생하기도 하고, 또는 전 통적인 조산사(Traditional Birth Attendant)의 비전문적인 분만지원으로 인해서 발 생하기도 하다.

위에서 언급된 직장질루, 방광질루, 산과적 누공, 질 원개 탈출증의 문제가 쉽사리 해결되지 않는 이유는 첫째로 $90 \%$ 이상의 분만이 전통적인 방식에 의해 집에서 이루 어지기 때문이다. 분만에 이상이 생겨도 적절한 지원을 받을 수 없게 된다. 또한 이 러한 질병으로 고통을 받는 여성의 경우 재건수술을 시행하면 $90 \%$ 정도의 성공률을 보임에도 불구하고 대다수의 여성들이 수술비를 감당할 수 없어서 이러한 혜택을 누 리지 못하고 있다.

이 지역 전통과 사회적 규범은 더욱 극복하기 어려운 문제이다. 여성할례가 지속 적으로 행해지고 있는 이유는 바로, 여아들이 여성할례를 통해서 사회적으로 받아들 여지고, 여성들 자신과 가족들의 명예를 유지하기 위해서, 결과적으로 여아들이 혼인 할 수 있도록 하기 위해서 이와 같은 관습이 지속적으로 행해지고 있다. 만일 할례 를 받지 않는 여성이 있다면, 이들은 사회에서 불결하고 심지어는 사회의 악으로 취 급받기 때문에 여성할례의 끔찍한 고통에도 불구하고 지속적으로 자행되고 있다.

그래서 월드비전은 1) 지역사회의 여성할례, 성차폭력(GBV), 여성보건과 관련된 이슈들에 대한 인식을 높이는 옹호활동; 2) 직장질루, 방광질루, 산과적 누공 피해여 
성들에게 의료적인 지원; 3) 피해여성들의 가족 및 지역사회 통합지원 및 생계지원의 목적으로 가지고 '여성보건지원사업(Fistula Victim Support Project)'을 진행하고 있다.

본 사업은 2012년 7월부터 1년간 시행되었던 사업으로, 사업지역은 소말리아의 소 말리랜드(Somaliland)의 토그드히어(Togdheer Region) 지역이다. 41명의 누공 (Fistula) 피해자들을 대상으로 의료지원 및 생계지원, 인식개선 활동을 실시하고 지 역사회를 대상으로 옹호사업도 실시하였다.

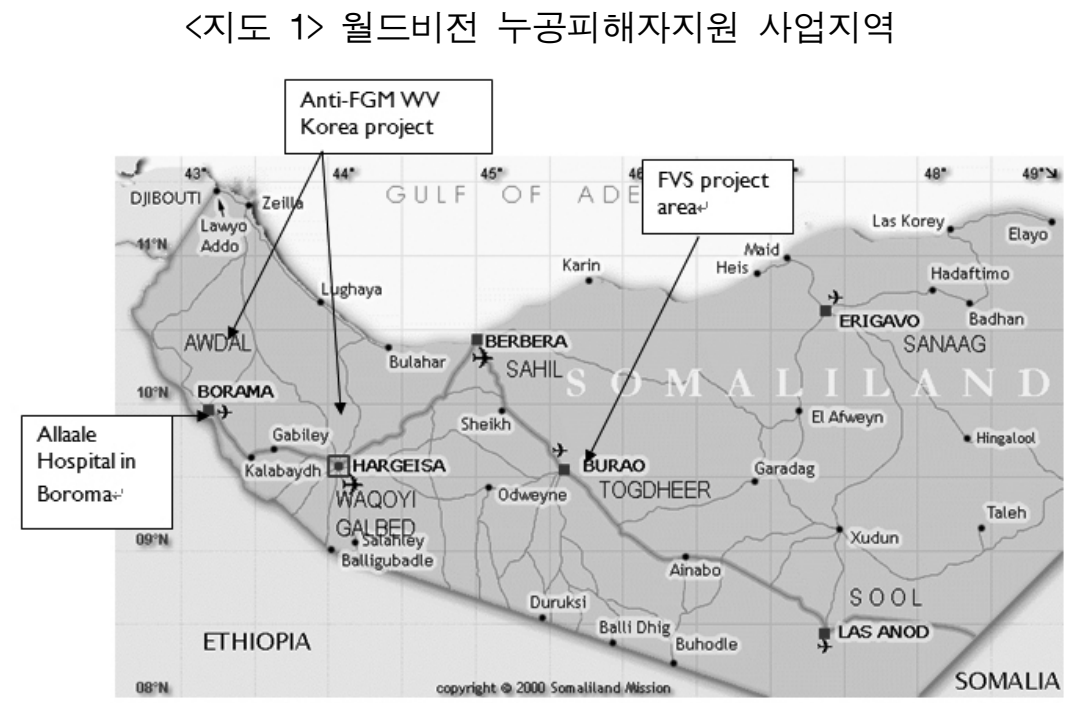

출처: World Vision South Sudan, 2014b

사업의 첫 단계는 지역에서 누공피해자들을 조사 및 파악하여 이들을 보라마에 위 치한 병원으로 데려가서 치료받도록 하는 것이다. 보통 누공 피해자들은 고통스러운 치료 및 수술을 받고 긴 회복시간을 보내야 하기 때문에 월드비전은 피해자뿐만 아 니라 동행할 수 있는 가족 중 한명이 동행할 수 있도록 지원한다. 이를 통해서 피해 자는 심리적인 안정감을 가지고 치료에 전념할 수 있게 된다.

치료를 마친 누공피해자들은 자조그룹을 조직하도록 하여 지속적으로 서로를 지원 할 수 있는 네트워크를 지원한다. 이 자조그룹을 통해서 서로의 어려움을 나누고, 치 
료의 과정을 통해서 자존감을 회복할 수 있게 된다. 월드비전은 이들에게 성차 (Gender) 및 인권에 대한 교육을 실시하여서 관련 이슈에 대한 인식을 높이도록 한 다. 더 나아가서 1 명당 6 마리의 염소를 나누어 주고 관련 기술을 전수하여 생계지원 을 도왔다. 이러한 과정을 통해서 여성들의 임파워먼트(Empowerment)가 실현되는 것이 본 사업의 기대효과이다.

\section{3) 부작용을 최소화하고 평화증진에 기여하는 사업(Do No Harm)}

분쟁국에서 진행되는 인도적 지원사업과 개발사업 기관들의 가장 큰 오해 중의 하 나는 그들이 진행하는 사업과 지원이 분쟁 당사자들에게 중립적(neutral)이고도 비당 파적(nonpartisan)이라는 믿음이다. 하지만 실제의 사례들을 눈여겨보면, 우리는 쉽 게 인도적 지원이나 개발 사업은 얼마든지 분쟁상황을 악화 내지 장기화할 수도 있 고, 누그러지게 할 수도 있다는 점이다. 그렇다면 우리가 해야 할 질문은 "어떻게 하 면 인도적 지원 혹은 개발사업이 분쟁상황을 악화시키지 않고 지역사회의 당사자들 로 하여금 분쟁과 그 원인을 감소하고 분쟁해결을 위한 대안을 만드는 방향으로 지 원될 수 있을까?”라고 요약할 수 있다(Anderson, 1999).

분쟁의 다면적인 원인(multidimensional factors)과 현지의 상황에 대한 철저하고 도 정확한 분석을 바탕으로, 현지 기관과 주민들의 역량을 과소평가하지 않고 의존 성을 줄이면서도 해당 지역의 취약성과 분열을 조장하지 않는 방향으로 정교하게 계 획된 인도적 지원과 개발사업은 분쟁으로 인한 고통을 감소하고 지속가능한 경제사 회적 효과가 있을 수 있게 된다. 결과적으로는 현지의 평화 정착에 기여할 수 있게 된다(Anderson, 1999). 'Do No Harm'의 원칙에 따라서 진행된 남수단과 미얀마의 사업을 통해서 어떻게 이러한 원칙이 사업으로 실현될 수 있는지를 주목하고자 한다.

(1) 남수단 교육 및 평화증진 사업(Education \& Peace-building Project in South Sudan): 평화에 대한 역량강화와 취약국에서의 교육사업의 양면성

남수단은 인도적 위기(Humanitarian Crisis)로 인한 어려움이 봉착해 있는 대표적 인 취약국이다. 2013년 12 월 15 일부터 수도 주바(Juba)에서 발생한 정치적 분쟁 
(Political violence)은 종족 분쟁(Ethnic conflict)으로까지 발전되어, 1백 3십만 명 의 국내 실향민과 4십만 명의 난민이 발생하였다. 대부분 여성과 아동으로 구성된 국내 실향민들은 음식, 식수, 기본적인 생필품, 주거지의 부족 등으로 고통 받고 있 으며, 지속되는 불안정과 분쟁의 위험으로 인해서 심리적인 고통(Psychological distress)에 시달리고 있다.

<지도 2> 사업지역 (Rejaf Payam, Juba County, Central Equatoria State, South Sudan)

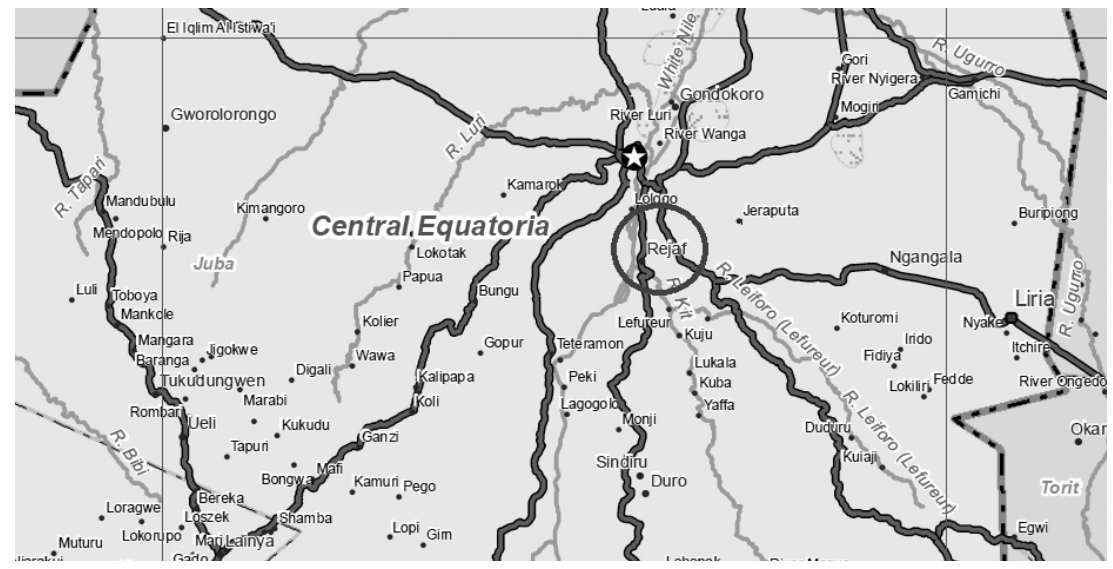

출처: OCHA, 2012

월드비전은 2008년부터 남수단 레자프 파얌지역에서 지역재건사업(Central Equatoria Area Rehabilitation Programme)을 실시하고 있었다. 사업 분야로는 1) 식량지원 및 생계지원 사업; 2) 교육; 3) 보호 사업을 지원하던 중이었다. 사업은 많 은 분야에서 진전이 있었지만, 2013년에 주바에서 발생한 정치적인 폭력상황은 다른 주로 전이되어서 전국적인 분쟁으로 발전되었다. 이로 인해 남수단에 있던 내외국인 직원들은 피신하고, 남수단의 월드비전 사업은 2013년 12월 15일부터 2014년 2월 16 일까지 월드비전의 남수단 사업이 잠정적으로 중단되었다.

이러한 과정을 거치면서 단순한 교육 사업을 넘어서서, 지역주민 특히 아동들을 대상으로 하는 평화의 역량과 인식을 향상시키는 교육과 평화증진사업을 실시하는 것을 계획하게 되었다. 2013년 분쟁발생 전인 11월에 월드비전이 Child Protection Analysis, Design and Planning Tool(ADAPT)라는 조사도구를 가지고 현장조사를 
실시했다. 평화와 관련된 문화와 인식을 조사하는 항목에서, $70 \%$ 의 소년과 약 $40 \%$ 의 소녀들은 해당지역사회가 술, 범죄, 폭력으로 인해 불안함을 느낀다고 응답하였 고, $60 \%$ 의 성인들의 경우에도 종족간의 분쟁으로 인해서 불안함을 느낀다고 응답하 였다. 흥미로운 점은 아동들의 경우에는 교회나 모스크 외에도 학교에서 가장 안전 함을 느낀다고 응답하였다는 점이다(World Vision South Sudan, 2014).

학교와 교육이 이렇게 긍정적인 영향을 미침에도 불구하고, 우려스러운 점은 2013 년 분쟁발생 이후 남수단 각 학교의 출석률이 급감하고 있다는 점이다. 또한 남수단 정부의 교육에 대한 지원 또한 현저히 줄어들고 있다. 더군다나 2005년에 포괄적인 평화협정(Comprehensive Peace Agreement)이 채결된 후에 다른 사업 분야에 비해 서 교육을 위한 지원이 현저하게 뒤처지는 것을 보면서, 수단 내의 교육 Cluster의 관계자들은 현재 진행 중인 분쟁으로 인해 남수단의 교육에 있어서 또 다른 세대를 잃을 수 있다는 우려를 표명4)하였다. 오히려 분쟁이 지속적으로 발생하는 남수단에 는 교육 사업에 대한 지속적인 지원이 장기적인 발전의 측면에서는 결정적인 요소가 됨에도 불구하고 시급성에 밀려서 지원을 받지 못하는 것이다.

물론 교육의 긍정적인 측면만을 일방적으로 강조해서는 안 되며, 교육이 가져올 수 있는 부정적인 측면에 대해서도 고려가 필요하다. INEE(Inter-Agency Network for Education in Emergencies)은 교육이 한 국가의 취약성을 강화시킬 수도 혹은 취약성의 원인과 결과를 감소시킬 수도 있다고 주장하고 있는데, 상당한 취약성을 가지고 있는 분쟁국에서 이 주장을 주목할 필요가 있다(INEE, 2011). 아래에서는 $\mathrm{INEE}$ 의 주장을 표로 정리해보았다.

4) Education Cannot Wait in South Sudan, Education is critical to averting another lost generation, South Sudan Education Cluster (Cited in World Vision South Sudan, 2014b) 
〈표 4〉 교육과 취약성의 영역의 상관관계

\begin{tabular}{|c|c|c|}
\hline $\begin{array}{l}\text { 취약성의 } \\
\text { 영역 }\end{array}$ & $\begin{array}{l}\text { 교육의 부정적 영향 } \\
\text { : 취약성 강화 }\end{array}$ & $\begin{array}{c}\text { 교육의 긍정적 영향 } \\
\text { : 취약성의 원인\&결과 감소 }\end{array}$ \\
\hline 거버넌스 & $\begin{array}{l}\text { - 공정, 평등하지 못한 교육에 대한 } \\
\text { 기회 (예: 지역별 교육기회의 } \\
\text { 차별) } \\
\text { - 교육의 공정성에 대한 불신으로 } \\
\text { 인해서 정부에 대한 불신으로 이어짐 } \\
\text { - 교육 분야에서의 부패로 인해서 } \\
\text { 학생들이 부패를 일상적인 삶의 } \\
\text { 방식으로 받아들임 } \\
\text { - 교육당국의 역량과 효율성의 } \\
\text { 부재로 인해서 문제의 소지가 } \\
\text { 있는 교육의 분산화 } \\
\text { (decentralization)로 이어짐 } \\
\text { - 교육시스템의 분열 }\end{array}$ & $\begin{array}{l}\text { - 수업비 철폐 등을 통한 교육의 } \\
\text { 기회 확대 } \\
\text { - 교육당국이 국민들의 필요를 } \\
\text { 채우기 위한 역량과 의지가 있음 } \\
\text { - 정치적인 조작에 대항하는 } \\
\text { 시민교육실시 } \\
\text { - 책무성의 시스템을 통한 부패에 } \\
\text { 대한 감소 } \\
\text { - 투명한 교육행정 } \\
\text { - 보호자-내담자(patron-client)의 } \\
\text { 체계를 통한 교육시스템 형성 }\end{array}$ \\
\hline 안전 & $\begin{array}{l}\text { - 교육의 소외와 주변인화 } \\
\text { (marginalization)을 통한 불만과 } \\
\text { 폭력이 증진됨 } \\
\text { - 교육의 군국화(militarization), } \\
\text { 폭력을 옹호하는 교육과정 } \\
\text { - 교육을 정치의 도구로 사용하거나 } \\
\text { 조작하여 타인에 대해서 편견을 } \\
\text { 조장하고 긴장과 폭력에 부추김 } \\
\text { - 생계활동에 대한 기대와 욕구에 } \\
\text { 교육과정이 부응하지 못함 } \\
\text { - 비판적인 사고의 발달을 } \\
\text { 저해하여, 정치적인 조작이나 } \\
\text { 젊은이들을 폭력에 동원하는 것에 } \\
\text { 대해서 무비판적이고 수동적으로 } \\
\text { 반응하게 함. }\end{array}$ & $\begin{array}{l}\text { - 교육을 통해서 아동들이나 } \\
\text { 젊은이들이 전투원으로 } \\
\text { 징집되거나 동원되는 것을 저해함 } \\
\text { - 여아들의 학교 등록률을 높임 } \\
\text { - 평화와 인권, 비폭력, 태도, } \\
\text { 행동에 대한 교육 실시 } \\
\text { - 지뢰에 대한 인식과 이해를 } \\
\text { 높여서 육체의 상해를 방지함 } \\
\text { - 육체의 징벌이나 성폭력에 대한 } \\
\text { 교사의 인식을 높이고 교사로서의 } \\
\text { 행동규범을 교육함 }\end{array}$ \\
\hline 경제 & $\begin{array}{l}\text { - 육체적 징벌을 통한 학교에서의 } \\
\text { 폭력으로 인해서 폭력을 삶의 } \\
\text { 방식으로 이해하도록 함 } \\
\text { - 학교교육과 경제의 현장과의 } \\
\text { 괴리로 인해서 교육이 경제발전에 } \\
\text { 기여를 하지 못함 }\end{array}$ & $\begin{array}{l}\text { - 국가의 봉급이 낮은 교사들에게 } \\
\text { 다른 생계수단을 지원(농사를 } \\
\text { 지을 수 있는 토지 및 종자 제공) }\end{array}$ \\
\hline $\begin{array}{c}\text { 사회적 } \\
\text { 영역 }\end{array}$ & $\begin{array}{l}\text { - 불신, 불관용, 분리된 정체성에 } \\
\text { 기반을 둔 편견과 분열의 특징을 } \\
\text { 가진 커리큘럼 } \\
\text { - 육체의 징벌, 교육의 접근성 배재, } \\
\text { 불평등을 조장하는 방식으로 } \\
\text { 교육에서의 차별이 존재 } \\
\text { - 성차별과 성폭력이 행해지는 } \\
\text { 교육현장 }\end{array}$ & $\begin{array}{l}\text { - 국가적인 정체성, 미래의 건설 } \\
\text { 등에 강조점을 둔 교육 } \\
\text { - 사회적 통합을 강조하는 세속적 } \\
\text { (Secular) 교육 } \\
\text { - 아동 인권과 평등에 대한 교육 } \\
\text { - 다른 민족/종족사이에 통합을 } \\
\text { 강조하는 교육 }\end{array}$ \\
\hline
\end{tabular}
(marginalization)을 통한 불만과 폭력이 증진됨

교육을 통해서 아동들이나 젊은이들이 전투원으로

징집되거나 동원되는 것을 저해함 평화와 인권, 비폭력, 태도, 행동에 대한 교육 실시 높여서 육체의 상해를 방지함

육체의 징벌이나 성폭력에 대한 교사의 인식을 높이고 교사로서의 행동규범을 교육함

다른 생계수단을 지원(농사를 지을 수 있는 토지 및 종자 제공) 


\begin{tabular}{c|c|c}
\hline $\begin{array}{c}\text { 취약성의 } \\
\text { 영역 }\end{array}$ & \multicolumn{1}{|c|}{$\begin{array}{c}\text { 교육의 부정적 영향 } \\
\text { : 취약성 강화 }\end{array}$} & $\begin{array}{c}\text { 교육의 긍정적 영향 } \\
\text { : 취약성의 원인\&결과 감소 }\end{array}$ \\
\hline \multirow{4}{*}{ 환경 } & $\begin{array}{l}\text { 환경이슈 (삼림파괴 및 에너지 } \\
\text { 보존)에 대한 커리큘럼화 실패 }\end{array}$ & \\
& $\begin{array}{l}\text { 토지권, 토지보유에 대한이슈, } \\
\text { 재난시에 토지에 관련된 이슈 } \\
\text { 커리큘럼화 실패 }\end{array}$ & - 관련 데이터 없음 \\
\hline
\end{tabular}

출처: INEE, 2011

이러한 인식을 바탕으로 월드비전은 교육 및 평화증진사업을 진행하였다. 이 사업 은 2 가지의 사업목표를 가지고 진행하는데, 한 가지는 공교육 내외의 세팅에서 남수 단 아동들의 읽고 쓰는 능력(Literacy)을 증진한다. 다른 한 가지는 남수단 아동과 청소년들에게 평화의 인식과 문화(역량)를 강화하는 것이다.

남수단 아동의 읽고 쓰는 능력 강화 목표 하에서의 사업 활동은 다음과 같다. 첫 째로, 사업지역에서 5 개의 대상학교를 선정하여 이들에게 관련 교육 자료를 제공한 다. 둘째로, 읽고 쓰는 능력을 가르칠 교사(Volunteer Teacher)의 교육 역량을 강화 한다. 이 활동은 현지조사를 통해 교사들의 역량이 강화될 필요가 있음이 확인되었 고, 교육계획, 수업준비, 실제 수업시행 등의 역량을 포함한다. 셋째로, 도시지역이 아닌 관계로 공교육의 혜택을 받지 못하거나 학교에서 중퇴한 아동들에 대한 읽기와 쓰기 능력을 월드비전이 이 지역에 이미 세운 아동친화공간(Child-friendly space) 에서 실시한다. 이 활동은 지역사회, 지역정부의 교육부서와 월드비전의 협력관계를 통해서 실현한다. 마지막으로, 지역사회의 교육에 대한 인식을 높이고 교육이슈에 적 극적으로 참여하도록 한다.

남수단 아동과 청소년들에게 평화의 인식과 문화(역량)를 강화하는 목표로 사업 활 동이 진행되었다. 월드비전은 남수단에서 2014년 10월 31일까지 Irish Aid의 지원을 통한 사업을 통해서 지역사회 내에 아동권리클럽(Child Rights Club)과 지역사회 보 호위원회(Community Protection Committee)를 조직하였고, 아동친화공간을 설립하 였다. 이러한 지역사회의 인프라와 조직된 네트워크를 바탕으로 본 사업은 지역사회 의 평화의 문화를 확산하고 역량을 키우는데 기여하려고 한다. 
본 목표 하에 사업 활동으로는 첫 번째로 평화증진자로서의 아동역량강화 (Empowering Children as a peace-builder)모델 하에 아동과 청소년을 대상으로 교육을 진행한다. 교육과정에는 평화증진, 양성평등, 의사결정, 차별의 위험, 상호존 중, 의사소통법 등이 포함되어 있다. 본 교육의 대상에는 아동권리클럽의 구성원들도 포함되고 약 6 개월 동안 진행된다. 두 번째로는 아동권리클럽과 지역사회보호위원회 가 주도가 되어서 지역 사회 내에 평화와 관련된 프로그램을 주체적으로 진행한다. 지역사회 행사, 캠페인, 라디오 메시지, 문화공연 등을 이들의 주도 하에 스스로의 계획으로 진행하도록 한다. 마지막으로, 얼마나 평화증진사업이 지역사회에 긍정적인 영향을 미쳤는지 모니터링과 평가를 실시한다.

(2) 미얀마 카친주 분쟁피해 주민 긴급지원사업(Emergency Support to Conflict Affected Communities in Kachin State, Myanmar): 수혜자 선정의 관점에서

난민(Refugee) 혹은 국내 실향민(International Displaced Persons: IDPs)이 위치 한 지역에서 식량지원사업 및 인도적 지원 사업을 진행할 때 사업지원의 수혜가 한 그룹에게만 지원될 때 때로는 인도적 지원이 지역사회의 분쟁을 가속화하는 경우가 있다. 대개 후원자 및 후원기관들은 분쟁 혹은 재난 발생 시에 난민 혹은 국내 실향 민의 필요에는 민감하지만 동일하게 분쟁으로 피해를 입은 지역 거주민(Host people)에게는 관심과 지원의 정도가 현저하게 낮은 경우가 많다. 결과적으로 인도적 지원이 역설적으로 난민 혹은 국내 실향민과 지역거주민 사이의 이원화(Dichotomy) 를 가속시키는 결과를 가져오게 된다.

카친주(Kachin State)는 미얀마 최북단의 주이며 중국과 인도 사이에 위치하고 있 다. 2011년 중반 카친주에 발생한 분쟁으로 인하여 2014년 2월을 기준으로 카친주와 샨주(Shan State)에 95,000명의 국내유민이 발생하였다. 1994년부터 2011년 6월까 지 지속된 정부군과 카친독립기구(Kachin Independence Organization)간의 무력 충돌은 곧 합의점을 찾을 것으로 예상된다. 지난 2 년 동안 카친주와 북부 샨주에는 국내 실향민이 계속 발생하고 있다. 
카친 정부군, 국제 $\mathrm{NGO}$, 지역사회조직, 종교 단체, 개인 기부자, 그리고 $\mathrm{UN}$ 기관 은 무력 분쟁 발생 초기 시점부터 인도적 지원을 제공하고 있으며, 그 중에서도 현 지 NGO와 종교 지도자들(교회 단체)은 취약 계층을 포함하여 인도적 지원 활동이 활발한 편이다. 월드비전 식량지원팀은 2008년부터 카친주 와잉마우(Waingmaw) 마 을에 거주하고 있는 국내 실향민들에게 식량을 지원하고 있으며, 2011년부터는 비식 량 물자, 거주지, 그리고 식수위생 지원을 하고 있다.

월드비전은 지역조사와 현지에서의 오랜 사업진행 및 모니터링을 통해서, 와잉마 우 지역의 모든 국내 실향민들은 $\mathrm{UN}$ 기관, 국제 $\mathrm{NGO}$, 그리고 종교 단체로부터 기초 적인 식량, 거주지, 그리고 기타 지원들을 제공받았지만, 국내 실향민이 아닌 주민들 혹은 현지 거주민들은 동일하게 무력 분쟁 피해를 입었음에도 불구하고 인도적 지원 기관으로부터 어떠한 지원도 받고 있지 않음을 파악하게 되었다. 현지 거주민들 또 한 기본적인 식량 및 생계 지원이 절실한 상태이고, 이 지역의 정치적으로 불안정한 환경으로 인해서 전통적인 생계 수단이었던 논과 삼림 지대에 접근하는데 어려움을 겪고 있었다.

이러한 문제점을 인식하고서, 2011년부터 9월부터 현재까지 한국 월드비전을 포함 한 월드비전 후원국의 지원으로, 국내 실향민들과 현지 주민들을 대상으로 식량, 비 식량 물자, 가정용품, 주방도구, 의료용품, 거주지, 식수위생(WASH), 생계, 그리고 겨울 대비를 위한 의류를 지원하였다. 또한 이들에게 식량 3,095 톤을 제공하였다. 하지만 인도적 지원에서 완전히 소외되었던 분쟁피해 거주민들을 위한 지원 사업이 필요하며, 사업 활동의 측면에서는 단기적인 지원을 넘어선 장기적인 효과가 있을 수 있는 생계지원사업이 병행되어야 함을 절감하게 되었다.

그래서 월드비전은 현지주민들이 거주하는 카친주 칩위지역 21 개 마을을 대상으로 2014년 8월부터 2015년 9월까지 461가구(총 2,240명)에게 식량지원과 함께 200가구 (총 1,000 명)에게 생계지원사업을 진행하기로 하였다. 사업계획을 수립하기 전에 진 행하였던 현지 조사(Assessment)를 통해서 식량 및 생계지원의 측면의 필요를 다음 과 같이 파악할 수 있었다. 1) 소득 감소: 분쟁으로 인하여 수천 명의 농부들이 농작 물과 가축을 잃었고, 대부분 논에서 쌀을 경작함으로써 생계를 유지하기 때문에 논 
경작을 하지 않으면 기본적인 식량을 얻을 수 없다; 2) 생계수단을 대체할 수 있는 자원 부족: 농경사회인 카친주에 거주하고 있는 주민들은 소규모의 농사에 의존하여 소득을 얻고 있으며, 현재 농업 이외에 다른 생계 수단이 없다; 3) 시장에 대한 접근 성 제한: 칩위 지역은 도로가 정비되어 있지 않는 등 기반시설이 열악하여 지역 주 민들이 식량을 포함한 기초적인 물자를 제공 받기가 어렵다; 4) 학교 입학률 감소: 빈곤이 증가함에 따라 부모들은 경제적인 어려움으로 인해 자녀들을 학교에 보낼 수 있는 역량이 부족하다.

현지 주민들은 타 기관으로부터 어떠한 지원을 받고 있지 않아, 기본적인 식량 지 원이 절실한 상태이다. 주민들은 전통적으로 하루에 세 끼를 섭취했지만 현재는 하 루에 한 끼로 살아가고 있으며, 아동들은 쌀 대신 옥수수를 섭취하고 있었다. 유엔 인도주의업무조정국(UN OCHA)에 의하면, 정부군 관할지역에는 질병과 영양실조에 대한 문제가 없지만, 정부군 관할이 아닌 지역의 주민들은 보건과 영양이 매우 취약 하기에, 다른 어떤 지원보다 식량 지원이 우선시 되어야 한다고 파악하였다. 또한 정 부군 관할 지역이 아닌 지역은 도로가 정비되어 있지 않는 등 기반시설이 열악하여 인도적인 지원을 받지 못하고 있었다.

이러한 문제분석을 바탕으로 2 가지 사업 활동을 계획하였다. 먼저 식량 지원 사업 으로서 월드비전은 효율적인 식량지원 및 생계지원을 위해 각 마을 지도자 대표들 및 정부 관계자들과 긴밀히 협력하는 것에 강조점을 두었다. 인도주의 사업 기준에 따라, 1 개월 동안 1 명을 기준으로 하여 쌀 $13.5 \mathrm{~kg}$, 콩 $1.8 \mathrm{~kg}$, 조리용 기름 $0.9 \mathrm{~kg}$, 그리고 소금 $0.15 \mathrm{~kg}$ 이 무력분쟁으로 피해를 입은 주민들에게 4 개월 5 개월(2014년 8 월 2014년 12월)동안 전달된다. 두 번째로는 주민들을 위한 생계지원 사업이다. 생 계지원의 구체적인 활동으로는 200 가구의 수혜주민들이 가축 지원을 받고, 역량 강 화를 위한 훈련을 제공받는 것이다. 또한 씨앗과 양수기와 같은 농업도구를 지원하 며, 가축을 사육하는 농부들이 적극적으로 농업에 종사하고 생산성을 높일 수 있도 록 가축 관리 기술을 제공한다.

결론적으로 월드비전은 카친 주에서 인도적 지원 사업에 있어서 국내 실향민과 거 주 주민들을 필요를 함께 인식하고 지원하였으며, 더 나아가서 인도적 지원 기관들 
의 지원이 아주 없던 칩위 지역 21 개 마을 주민들을 대상으로 하는 식량지원과 생계 지원 사업을 계획하였다. 그동안 후원자의 관심뿐만 아니라, 실제적인 지원에 있어서 철저하게 소외되었던 현지주민들의 절박한 필요를 지원하려고 하였다. 인도적 지원 에 있어서는 정파, 종교, 인종 등의 차별을 두지 않고 오직 현지의 필요(need)에만 기인해야 한다는 인도적 지원원칙 중 비편파성(Impartiality)에 근거를 두어 최대한 인도적 지원으로 인한 부작용과 폐해를 감소하려고 노력하였다. 더군다나 칩위 지역 은 정부군 관할지역이 아닌 탓에 도로가 부실하여 접근성이 현저하게 낮은 관계로 더욱더 인도적 지원에서 소외되었기에 정치상황에 구애받지 않고 현지 주민의 필요 에 근거를 두었다.

\section{IV. 결론과 제언}

$\mathrm{DFID}$ 는 분쟁국을 포함한 취약국에서 취약국의 관계자들과 일하는 것은 '어렵고, 비용이 많이 들고, 상당한 위험을 감수하는 일이라고 묘사하고 있다. 그래서 많은 후원기관(Institutional donors)들은 이 지역에서 단기간의 긴급구호사업만을 지원하 고 물러나는 방법을 택하곤 한다(DFID, 2005). 실제로 후원기관들은 지원대비 효과 성일 보장될 수 있는 빈곤 국가들을 선호하기 때문에 한 조사에 따르면 취약국들은 개발사업의 부족한 성과로 인해서 상대적으로 좋은 성과를 보여주는 국가들5)보다 $43 \%$ 적은 지원을 받는다는 결과가 나와 있다(Dollar et al., 2005). 한마디로 분쟁국 을 포함한 취약국의 낮은 성과는 향후 적은 지원으로 귀결된다고 볼 수 있다.

\section{1. 분쟁국의 낮은 성과의 이유}

그렇다면 분쟁국을 포함한 취약국들이 보여주는 낮은 성과(Poor Performance)의 원인은 무엇인가? 그 오직 그들에게만 돌릴 수 있을까? 그 원인은 다음과 같이 정리 해볼 수 있다. 첫째로, 취약국 대부분에 제공되는 지원들은 실제 필요에 비추어서 상 당히 적다. 그 이유는 취약국들의 낮은 성과 때문이기도 하지만, 필요보다는 다른 원 인에 의해서 좌우되는 후원기관들의 자금 배분 우선순위 때문(Donor-driven

5) 후원기관들이 선호하는 효과적인 국가들은 상대적으로 효과적인 정부시스템과 안정적 인 경제 정책을 가진다는 특징을 보여 준다(Dollar et al., 2005). 
Priority)이기도 하다. 〈그림 2〉는 1992년에서 2002년 사이에 취약국의 필요와 그들 이 실제로 받은 지원의 간극을 보여주고 있다(DFID, 2005).

둘째로는 지원의 타이밍이다. 많은 지원들이 미디어의 주목, 정치적인 중요성, 분 쟁의 양상 등에 따라서 좌우되기 때문에 장기적인 분쟁(Protracted Crisis) 혹은 장 기 난민상황 등은 엄청난 지원이 필요함에도 불구하고 많은 지원을 받지 못하고 있 다. 실제로 2013년 3월에 발생한 Seleka가 권력을 쟁취하면서 발생한 분쟁상황 이전 의 중앙아프리카 공화국의 사례가 그러하다. 실제로 UN의 경우에는 Consolidated Appeal에 비해서 실제 지원된 자금은 2010년에 48.4\%, 2011년에는 45.9\%뿐이었다. 자금부족의 문제뿐만 아니라 경험 있고 전문성 있는 인력들도 상당히 부족한 상황이 었고, 이 국가에서 일하는 국제 NGO도 소수였을 뿐만 아니라 대부분 분쟁에 영향을 받은 남동부에만 집중되어 있었다. 하지만 2013년 분쟁발생 이전에도 장기간의 인도 적 위기상황으로 인해서 지역주민들의 사망률, 특히 5 세 이하 어린이의 사망률이 재 난상황의 차원을 뛰어넘는 수준이었다고 2011년 국경없는 의사회 보고는 보고하였다 (Picco, 2014).

\section{<그림 2> 취약국에 지원되는 실제 지원 대비 적정한 지원의 차이6)}

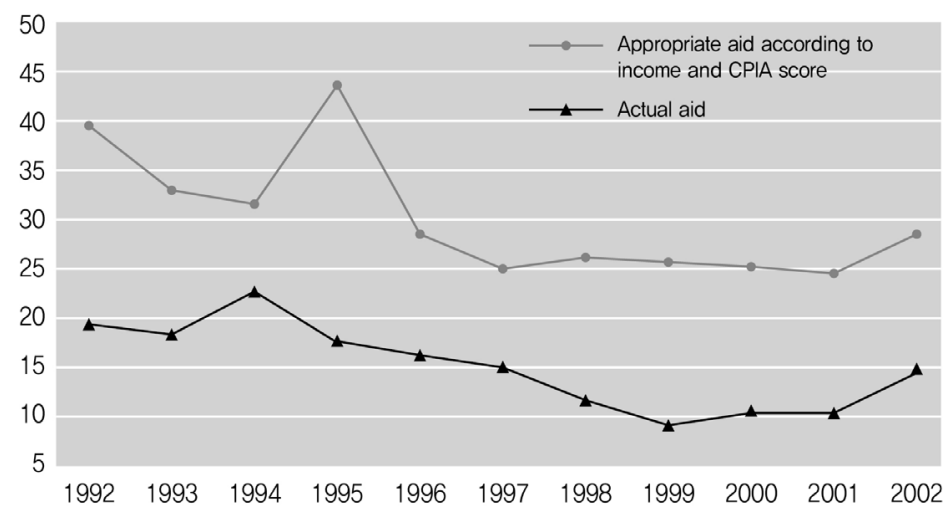

출처: Dollar et al., 2005

또한 경험적인 측면에서 보면, 분쟁국은 후원기관이 제시하는 사업지원기금의 조 건이나 가이드라인을 지키지 못하는 경우가 많다. 분쟁국에서 발견되는 개발사업과

6) Actual versus appropriate aid per capita flows to fragile states(1992-2002) 
인도적 지원사업의 엄청난 필요와 취약인구에도 불구하고, 분쟁국의 역량부족 및 비 협조, 사회자본, 인력의 문제, 높은 인력 및 운영비, 불안정 등의 이유로 인해서 사 업이 지연되거나, 사업비 지출에 있어서 실제 운영비 지출비중이 결과적으로 높아지 는 등의 이슈가 발생하는 경우가 있다. 이러한 요소들이 차후에 추가적인 지원으로 연결되지 못하는 결과로 이어진다.

\section{2. 분쟁국에서의 더 효과적인 사업을 위한 제언}

그렇다면 이러한 도전에도 불구하고 향후에 분쟁국을 포함한 취약국에 대한 지원 은 어떠한 방향으로 이어져야할 것인가? 우선 취약국에 대한 인도적 지원 및 개발 사업은 그 지역 상황에 대한 정확한 이해를 바탕으로 진행되어야 한다. 장기적 분쟁 으로 인해서 한 국가의 거버넌스 및 기본적인 기능이 현저하게 부족하거나 부재가 왜 발생했는지에 대한 정확한 분석과 이해를 바탕으로 접근이 이루어져야 한다.

보통 취약국 실패의 이유를 해당국가의 의지(Will)에서 찾는 경우가 있고 혹은 역 량(Capacity)에서 찾는 경우가 있다. 〈그림 3〉을 보면 취약국 중 미얀마(혹은 버마) 와 북한은 국가의 의지가 부족한 국가들이다. 대체로 국민에 대해서 억압적인 국가 들이 여기에 속한다. 반면 국가의 역량이 콩고민주공화국, 동티모르(Timore Leste), 남수단 같은 국가들이 여기에 속한다. 본 그림에 나오지는 않지만 남수단도 여기에 해당하는 국가로 볼 수 있다. 대체로 신생국이거나 분쟁으로 인해서 국가의 역량을 축척할 기회를 놓친 경우가 이에 해당한다. 혹은 소말리아 같이 국가의 체계가 철저 히 무너진 경우도 있다. 물론 여기에서 의지와 역량이라는 범주로 나누기는 했지만 같은 범주의 국가들이라고 할지라도 또 특정한 역사적 사회적 원인들이 있다. 모든 분쟁국이 다른 배경과 원인으로 현재의 상태로 귀결되었기에 다른 접근방법과 사업 전략을 가지고 접근해야 한다. 그러기에 후원기관, 인도적 지원 및 개발기관들 모두 해당국가의 상황과 배경에 대한 정확한 분석과 이해를 위한 전문가 양성 및 더 많은 지원과 투자가 필요하다. 현장에 대한 정확한 분석과 이해를 바탕으로 한 사업이야 말로 각 현장에 특정한 필요들을 정확하게 채울 수 있고, 인도적 지원 및 개발 사업 으로 인한 의도하지 않았던 부작용들을 최소화할 수 있는 길이다. 


\section{<그림 3> 분쟁국의 실패의 이유: 의지 혹은 역량}

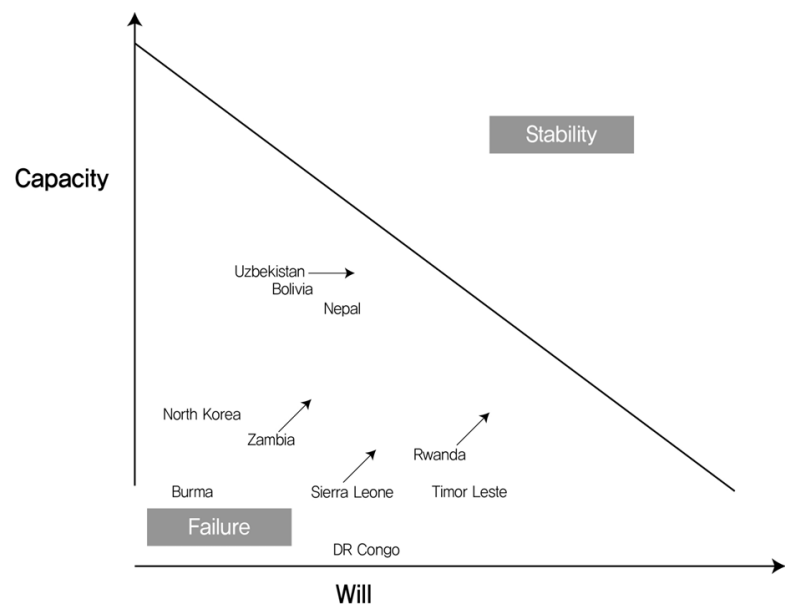

출처: Browne, 2007

또한 관련 기관들이 분쟁국을 포함한 취약국 지원에 있어서 현장의 필요를 효과적 으로 채울 수 있는 전략모색이 필요하다. 우선적으로는 분쟁 후의 단기적인 지원에 서 벗어나 포괄적이고도 분쟁예방을 위한 방향성을 가질 필요가 있다. 한 조사에 의 하면 분쟁예방을 위한 지원 사업을 통해서 분쟁 후 대응사업의 4 배의 효과를 기대할 수 있다고 보고하고 있다(Chalmers, 2004). 둘째로는 취약국의 사업에 대해서는 단 순히 비용대비의 효과성(Cost effectiveness)의 시각을 벗어나 장기적인 차원에서의 투자를 통한 변혁을 지향점으로 삼아야 한다. 구체적으로는 개발 사업이 해당국가의 역량(Capacity)과 거버넌스를 강화하는 방식으로 좀 더 전략적인 지원이 이루어져야 한다. 결국은 분쟁국의 거버넌스와 기본적인 국가기능이 회복되는 것이 장기적인 국 가의 변화에 지속가능한 효과가 있기 때문이다. 또한 후원기관 또한 취약국 사업에 는 좀 더 유연한 사업가이드라인이 적용될 필요가 있다. 개별 사업의 결과로만으로 판단할 것이 아니라, 좀 더 장기적인 지원전략의 틀 안에서 향후 분쟁국을 위한 지 원이 진행되기를 바란다. 


\section{참고문헌}

권경성 (2008), 구도와 재생을 위해 떠나는 여행, 미디어 오늘

(accessed November 2014

http://www. mediatoday.co.kr/news/articleView. html?idxno= 65334)

한국 월드비전 (2010), 우간다 북부 울 지역재건사업 KOICA 제안서, 서울: 월 드비전

한국 월드비전 (2011), 수단 마요지역재건사업 KOICA 제안서, 서울: 월드비전 Anderson M. B. (1999) Do No Harm: How Aid Can Support Peace or War, London: Lynne Rienner Publishers

Browne, S. (2007) Aid to Fragile States: Do Donors Help or Hinder? Discussion Paper 2007/01 United Nations University

Brooking Institute (2008) Index of State Weakness in the Developing World (accessed

http://www. brookings. edu/research/reports/2008/02/weak -states-index)

Chalmers, M. (March 2004), Spending to Save? An Analysis of the Cost Effectiveness of Conflict Prevention versus Intervention after the Onset of Violent Conflict, Centre for International Cooperation and Security, Department for Peace Studies, University of Bradford.

Dollar, D. and Levin, V. (2005) 'The Forgotten States: Aid Volumes and Volatility in Difficult Partnership Countries (1992-2002)' Summary Paper Prepared for DAC Learning and Advisory Process on Difficult Partnerships.

DFID (2005) Why we need to work more effectively in fragile states London: DIFD

Foreign Policy (2014) Fragile State Index(accessed

http://www. foreignpolicy.com/fragile-states-2014\#rankings) 
INEE (2011) Understanding education's role in fragility Synthesis of four situational analyses of education and fragility: Afghanistan, Bosnia and Herzegovina, Cambodia, Liberia, Paris: IIEP and UNESCO(accessed http://unesdoc. unesco. org/images/0019/001915/191504e.pdf)

Institute for Economics and Peace (2014) Global Peace Index. New York: IEP (accessed

http://www. visionofhumanity.org/sites/default/files/2014\% 20Global\%20Peace\%20Index\%20REPORT.pdf)

Midgley T. and Anderson S. (2011) IPM without Sponsorship: Interim report

OCHA (2012), Central Equatoria State Map, (accessed https://docs, unocha.org/sites/dms/SouthSudan/ReferenceM ap_CentralEquatoriaState_A4_March2012.pdf )

Picco, E. (2014) Central Africa Republic: Fragile State, Fragile Response in HPN (ed), The Crisis in the Central African Republic, Number 62 September 2014, London: HPN

Robert, B et al. (2008) Factors associated with post-traumatic stress disorder and depression amongst internally displaced persons in northern Uganda, BCM Psychiatry 8(38)

World Vision (2011) Handbook for Development Programmes: the essentials (accessed November 2014, http://www.wvi.org/guidancefordevelopmentprogrammes)

World Vision (2012) What is MSTC? (accessed November 2014, http://www.wvi.org/peacebuilding-and-conflict-sensitivit y/publication/what-mstc )

World Vision (2013) Making Sense of Turbulent Context (MSTC): Analysis tool for Humanitarian Actors (accessed November 2014 http://www. conflictsensitivity. org/print/85)

World Vision Myanmar (2013), Proposal of Emergency Support to Conflict affected communities in Kachin State, Myanmar, Yangon: WV 
World Vision Somalia (2012), Proposal of Fistula Victim Support Project-Somalia, Somalia: WV

World Vision South Sudan (2014a), ADAPT Data Collation

World Vision South Sudan (2014b) Education \& Peace-building Project, Juba: WV

UNDP (2003). Conflict-related Development Analysis (CDA). New York: UNDP. Available at:

www.undp.org/bcpr/conflict_prevention/ca_note\%20_2_.pdf

UNDP (2014). Human Development Report, 2003. New York: Oxford University Press. Available at:

http://hdr.undp.org/sites/default/files/hdr14-report-en-1. pdf 